\title{
Penerapan Art Therapy untuk Menurunkan Depresi pada Lansia di Panti Werdha X
}

\author{
Ayu Eka Permatasari ${ }^{1}$, Samsunuwiyati Marat ${ }^{2}$, dan Meiske Y. Suparman ${ }^{3}$ \\ ${ }^{1}$ Jurusan Psikologi, Universitas Tarumanagara Jakarta \\ Email:aepermatasari@gmail.com \\ ${ }^{2}$ Fakultas Psikologi, Universitas Tarumanagara Jakarta \\ Email: samsunuwiyatimarat@yahoo.com \\ ${ }^{3}$ Fakultas Psikologi, Universitas Tarumanagara Jakarta \\ Email: meiskeyunithree@gmail.com
}

\begin{abstract}
Aging process on elderly can be challenging. Elderly who lives with their family can enjoy happiness and independent live. But, it is different with elderly who lives in a nursing home. Elderly who live in a nursing home often feel lonely, lack of activity, and experience stress to depression. They tend to show symptoms of depression which are sense of helplessness, avoidance of social interaction, experience physical complaints such as headaches, back pain, digestive disorders, and indisgestion. This research is aimed to know whether the application of art therapy can reduce depression on the elderly who lives in a nursing homes. Art therapy intervention with with drawing and coloring methods were chosen because it can be applied to individual of all ages. This intervention is aimed to express feelings, changing negative thoughts, and to be able to more recognize them selves. Participants of this research were 3 elderly who live in nursing homes. The intervention was conducted for 12 sessions. The results were being measured by comparing the pretest-posttest score of Geriatric Depression Scale (GDS). After the intervention was conducted, all participants showed reducing score of depression on GDS on posttest score. During the intervention, all participant also showed process of increasing expressions on their artwork. The results also indicated changes of their behaviors such as increasing social interaction.
\end{abstract}

Keywords: Art therapy, Elderly, Depression, Gerontology, Nursing homes.

Lanjut usia (Lansia) adalah suatu proses hidup yang akan dilalui oleh setiap manusia. Tugas perkembangan seorang lansia yang harus dipenuhi adalah melakukan penyesuaian diri dengan penurunan dan perubahan yang terjadi secara fisik ataupun mental, melakukan sosialisasi dengan rekan sebaya, serta melakukan adaptasi dan pengaturan kehidupan yang menyenangkan (Cohen, 2000). Berdasarkan hasil sensus penduduk tahun 2010, menunjukkan bahwa Indonesia termasuk lima besar negara dengan jumlah penduduk lansia terbanyak di dunia. Pada tahun 2010 jumlah lansia di Indonesia mencapai 18,1 juta orang. Sementara itu Data Susenas Badan Pusat Statistik (BPS) tahun 2012 menunjukkan lansia di Indonesia sebesar 7,56\% dari total penduduk Indonesia. Bappenas memperkirakan pada tahun 2050 akan ada 80 juta lansia di Indonesia dengan komposisi usia 60-69 tahun berjumlah 35,8 juta, usia 70-79 tahun berjumlah 21,4 juta dan 80 tahun ke atas ada 11,8 juta. Menurut data tersebut, sebagian besar lansia di Indonesia berjenis kelamin perempuan (Wardhana, 2014).

Menurut Indrawari dan Saputri (2011) individu yang berusia lanjut akan menjadi sangat rentan terhadap gangguan kesehatan, termasuk depresi yang disebabkan oleh stress dalam menghadapi perubahan-perubahan pada kehidupan. Lanjut usia yang terus meningkat jumlahnya di Indonesia memunculkan kenyataan baru, yaitu semakin banyak jumlah lansia yang tinggal di panti-panti werdha. Aktivitas yang dijalani lansia di panti werdha kebanyakan sangat monoton dan tidak bervariasi sehingga membuat kehidupan yang dijalani oleh lansia terasa datar. Hal tersebut membuat orang tua yang memasuki usia lanjut semakin merasa terabaikan secara sosial dan psikologis sehingga individu lansia memiliki kecenderungan untuk mengalami gangguan kesehatan, salah satunya adalah depresi. 
Depresi merupakan gangguan mental yang sering terjadi di tengah masyarakat. Berawal dari stress yang tidak diatasi, maka seseorang dapat masuk ke fase depresi. Rathus (dalam Lubis, 2009) menyatakan bahwa individu yang mengalami depresi umumnya menunjukkan gejala psikis, gejala fisik dan gejala sosial yang khas, yaitu: (a) Gejala fisik, seperti: gangguan pola tidur, menurunnya tingkat aktivitas, menurunnya efisiensi kerja, menurunnya produktivitas kerja, dan mudah merasa lelah serta sakit; (b) Gejala psikis, seperti: kehilangan rasa percaya diri, sensitif, merasa diri tidak berguna, memiliki perasaan bersalah, dan persaan yang terbebani; (c) Gejala sosial, seperti: masalah interaksi dengan rekan kerja, perasaan minder dan cemas jika berada di antara kelompok, tidak nyaman berkomunikasi dengan orang lain, dan tidak mampu bersikap terbuka atau menjalin hubungan dengan lingkungan (Lubis, 2009).

Blazer (2003) mengungkapkan bahwa prevalensi depresi pada lansia berjenis kelamin wanita lebih tinggi dibandingkan dengan pria. Wanita memiliki risiko untuk depresi lebih tinggi daripada pria, bahkan di masa tua. Pada studi yang sudah dilakukan, terbukti prevalensi depresi pada pria sebesar 6,9\% dan $16,5 \%$ terjadi pada wanita. Depresi pada lansia tidak hanya ditunjukkan melalui perubahan perilaku yang menurun dari biasanya, akan tetapi terdapat keluhan fisik yang menyertai gangguan depresi pada lansia. Gejala fisik yang dapat menyertai depresi dapat bermacam-macam seperti sakit kepala, jantung berdebar-debar, sakit pinggang, gangguan gastrointestinal, mudah merasa lelah dan mengalami penurunan berat badan (Gallo \& Gonzales, 2001).

Oleh karena itu, diperlukan intervensi yang tepat bagi lansia untuk menurunkan depresi yang dialami dengan memberikan kegiatan yang positif, menarik dan bersifat menyenangkan. Salah satunya adalah dengan art therapy. Malchiodi (2013) menyatakan art therapy adalah suatu bentuk terapi yang bersifat ekspresif dengan mengunakan materi seni, seperti lukisan, kapur, spidol, dan lainnya. Art therapy menggunakan media seni dan proses kreatif untuk membantu mengekspresikan diri, meningkatkan keterampilan coping individu, mengelola stress, dan memperkuat rasa percaya diri. Art therapy juga dapat diartikan sebagai kegiatan membuat sebuah karya seni untuk memenuhi kebutuhan psikologis dan emosional pada individu, baik pada individu yang memiliki kemampuan dalam seni ataupun yang tidak memiliki kemampuan dalam seni. Melalui art therapy individu dapat mengungkapkan perasaan yang dialami dengan menggunakan seluruh area atau fungsi dalam diri mereka (Malchiodi, 2013).

Art therapy dapat menjadi cara yang tepat untuk mengungkapkan emosi, seperti: perasaan marah, takut ditolak, cemas, dan rendah diri. Kegiatan yang diperoleh dalam art therapy itu sendiri salah satunya melalui menggambar. Kegiatan menggambar merupakan kegiatan yang menyenangkan dan dapat dilakukan oleh siapapun sekalipun individu tersebut tidak dapat menggambar. Melalui media gambar tersebut, dapat membantu memahami persepsi dan perasaan yang terjadi pada diri individu dan mencoba membantu menggali bagaimana cara menyelesaikan masalah. Dan harapan untuk dapat membantu untuk hidup lebih baik dan tidak terjebak dalam masa lalu (Adriani \& Satiadarma, 2011).

Malchiodi (2012) dan Bolton (2008) menyatakan media yang digunakan dalam proses art therapy sangat bervariasi. Namun hanya terdapat empat media kasar yang digunakan sudah lebih dari 60 tahun, yaitu painting, clay, collage, dan drawing. Kegiatan menggambar merupakan kegiatan yang menyenangkan dan dapat dilakukan oleh siapapun sekalipun individu tersebut tidak dapat menggambar. Melalui media gambar, individu akan memahami persepsi dan perasaan yang terjadi pada dirinya dan membantu individu untuk menggali cara menyelesaikan masalah serta menemukan harapan untuk membantu hidup menjadi lebih baik (Adriani \& Satiadarma, 2011). 
Menurut Bolton (2008) art therapy dapat diterapkan melalui single media dengan memilih satu dari empat media atau dengan mix media (metode campuran), yaitu menggunakan atau menerapkan art therapy dengan lebih dari satu media. Landgarten (2013) juga menyatakan kegiatan art therapy bagi lansia harus memerhatikan pemilihan media serta materi yang digunakan. Hal ini penting agar dapat menyesuaikan pada kemampuan dan kebutuhan lansia yang mengikuti kegiatan art therapy. Selain itu, menggunakan mix media juga membantu untuk meningkatkan potensi diri pada lansia karena dapat mencoba berbagai media selama intervensi berlangsung.

Rubin (2010) menyatakan bahwa tujuan dalam pemberian teknik art therapy adalah untuk membantu individu menggapai tujuan, seperti mengungkapkan apa yang dirasakan, katarsis, atau meningkatkan self esteem pada individu. Stephenson (2006) menambahkan bahwa proses terapeutik dalam art therapy salah satunya menekankan pada proses kognitif dengan harapan dapat membangkitkan emosi positif dan meningkatkan kemampuan memori pada individu. Melalui art therapy, diharapkan lansia dapat menghadapi perbaikan fisik, emosi, dan pengaruh lingkungan dengan cara yang baru.

\section{Rumusan Masalah}

Apakah art therapy dapat diterapkan untuk menurunkan depresi pada lansia di panti werdha X?

\section{Tujuan Penelitian}

Tujuan dari penelitian ini adalah mengaplikasikan art therapy untuk membantu menurunkan depresi dan meningkatkan kesejahteraan pada lansia di panti werdha.

\section{Metode Penelitian}

Partisipan Penelitian. Karakteristik partisipan dalam penelitian ini, antara lain: (a) individu berjenis kelamin perempuan, (b) sedang berada dalam tahapan lanjut usia (lansia) 60-70 tahun, (c) partisipan sehari-harinya tinggal dan menetap di panti werdha X Jakarta Barat, (d) partisipan mengalami gangguan depresi yang didapatkan dari hasil tes yang diberikan, dan (e) partisipan memiliki kemampuan fisik yang baik untuk dapat berkomunikasi dan menjalani proses intervensi. Penelitian ini tidak dibatasi oleh suku bangsa atau ras, agama, dan status sosial.

Desain Penelitian. Desain penelitian yang digunakan dalam penelitian ini adalah mixed method dengan menggabungkan metode penelitian secara kuantitatif dan kualitatif dalam satu penelitian. Penelitian ini menggunakan pre-test dan post-test sebagai analisa untuk menentukan kriteria partisipan dan mengetahui perbandingan hasil sebelum dan sesudah pemberian intervensi.

Lokasi Penelitian. Lokasi penelitian dilakukan di panti werdha X Jakarta Barat.

Instrumen Penelitian. Peralatan yang digunakan peneliti adalah lembar informed consent, lembar observasi, recorder, alat ukur Geriatric Depression Scale (GDS), alat tulis, kertas gambar, pensil warna, crayon dan cat poster.

Pengukuran. Alat ukur yang digunakan untuk mengetahui tingkat depresi lansia dengan menggunakan Geriatric Depression Scale (GDS). Alat ukur GDS terdiri dari 15 pernyataan untuk mengukur tingkat depresi yang dialami lansia. Hasil uji validitas yang telah dilakukan pada lansia di panti werdha menyatakan alfa cronbach $(\alpha)=0,819$. Hasil ini menyatakan bahwa penelitian menggunakan GDS layak dilakukan karena cocok dan valid digunakan untuk 
mengukur tingkat depresi pada lansia di panti. Reliabilitas yang dimiliki alat ukur ini cukup baik dengan correlates significantly of 0,85 .

Prosedur Penelitian. Pada prosedur awal penelitian, peneliti akan meminta ijin dengan mengantarkan surat permohonan melakukan penelitian di panti werdha X Jakarta Barat. Setelah itu, peneliti mulai mencari partisipan sesuai karakteristik penelitian. Peneliti akan memberikan pre test terlebih dahulu untuk mengetahui rentang depresi pada lansia yang berada di panti werdha X. Peneliti juga melakukan metode observasi dan wawancara guna menguatkan hasil pre test yang diberikan pada partisipan penelitian.

Pelaksanaan Intervensi. Intervensi melalui art therapy pada partisipan dilakukan sebanyak 12 sesi melalui metode menggambar dan mewarnai. Tahapan sesi dari intervensi art therapy yang diberikan menggunakan lima tahap dari Ganim (2013) yaitu: (a) Tahap Pertama, diadakan sebanyak 3 sesi. Partisipan akan diminta untuk menggambar bebas yang bertujuan sebagai media ekspresi perasaan partisipan melalui gambar. Selain itu, hal ini juga sebagai langkah awal partisipan untuk beradaptasi dan membiasakan diri pada art therapy; (b) Tahap Kedua, diadakan sebanyak 2 sesi. Pada tahap ini partisipan diminta untuk menggambarkan hal yang tidak menyenangkan selama berada di panti dan menggambarkan situasi partisipan sebelum berada di panti yang bertujuan untuk meningkatkan kesadaran diri partisipan; (c) Tahap Ketiga, diadakan 1 sesi. Partisipan diminta untuk menggambarkan rasa sakit atau tidak menyenangkan yang dirasakan pada tubuh partisipan yang bertujuan agar partisipan mengenali tanda atau sinyal pada tubuhnya sehingga lebih mudah untuk memulihkannya; (d) Tahap Keempat, diadakan sebanyak 2 sesi. Partisipan akan diminta untuk menggambar mandala, tujuannya untuk membantu partisipan mengenali inner self yang dimiliki sehingga membebaskan jiwa dan menemukan insight potensi pada partisipan untuk kehidupannya; dan (e) Tahap Kelima, diadakan 3 sesi. Partisipan akan diminta untuk menggambarkan situasi lingkungan saat ini, menggambarkan hal yang menyenangkan untuk dilakukan, dan mandala. Tujuannya untuk membantu partisipan memahami lingkungan sekitarnya, melatih empati serta menemukan arti kehidupan, dan membaskan diri dari emosi negatif yang dimiliki.

Selain menjalani intervensi art therapy, ketiga subyek penelitian akan mendapatkan materi tambahan mengenai teknik relaksasi. Peneliti akan memberikan teknik relaksasi saat seluruh subyek selesai menjalani intervensi pada sesi ke empat saat subyek menggambarkan hal yang tidak menyenangkan selama berada di panti dan pada sesi ke enam saat subyek diminta untuk menggambar rasa sakit/tidak menyenangkan pada tubuhnya. Menurut Malchiodi (2007) umumnya individu akan memikirkan hal negatif dan memunculkan ketegangan pada diri individu saat menjalani proses terapi yang menugaskan mereka pada suatu kondisi yang kurang menyenangkan. Oleh karena itu, peneliti menambahkan sesi relaksasi setelah partisipan menyelesaikan tugas pada sesi ke 4 dan ke 6 . Hal ini dilakukan untuk membantu individu melepaskan ketegangan yang dirasakan setelah menjalani intervensi yang menugaskan subyek untuk menggambarkan sesuatu yang kurang menyenangkan. Setelah sesi selesai, peneliti akan meminta subyek untuk duduk dengan posisi yang nyaman sambil memejamkan mata dan mengikuti instruksi yang diberikan oleh peneliti.

\section{Hasil Intervensi}

Jika dilihat pada Gambar 1. MA terlihat memiliki perubahan yang terlihat cukup signifikan. Sebelumnya MA menunjukkan perilaku seperti kehilangan minat untuk melakukan aktivitas, kontrol emosi lemah, memiliki interaksi sosial yang rendah, mengalami kesulitan tidur, konsentrasi menurun, dan memiliki rasa kepercayaan diri yang rendah. Ia juga mengungkapkan 
perasaannya yang sering merasa kosong atau hampa, tidak memiliki semangat, dan merasa dirinya tidak berdaya. Selama menjalani intervensi, ia terlihat memiliki perubahan dari setiap sesi yang ia jalani. Pada sesi-sesi awal terlihat MA masih memiliki tekanan garis yang tegas dan tidak beraturan. Begitu juga dari pemilihan warna yang cenderung gelap dan didominasi oleh warna-warna yang menunjukkan amarah, seperti warna merah. Komposisi bentuk serta ruang pada gambar juga menunjukkan kekosongan dan kesendirian pada diri MA. Gambar yang MA buat seringkali berukuran kecil dan masih menyisakan banyak ruang pada kertas. Namun, mulai dari sesi lima gambar MA sudah terlihat mulai mengalami perubahan baik dari ukuran maupun warna yang dipilih.
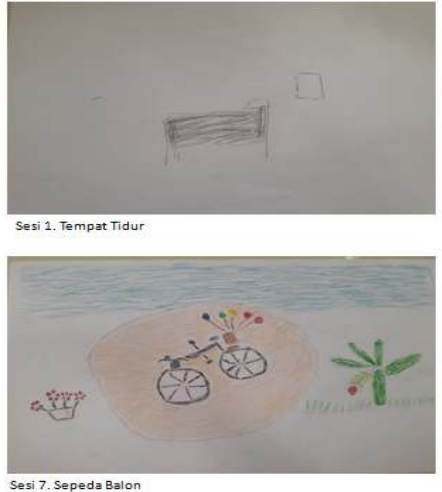

Gambar 1. Hasil Intervensi Subyek 1 (MA)

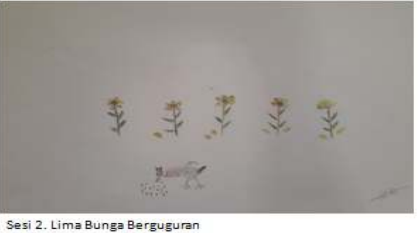

Sesi 2. Lima Bunga Bergugura

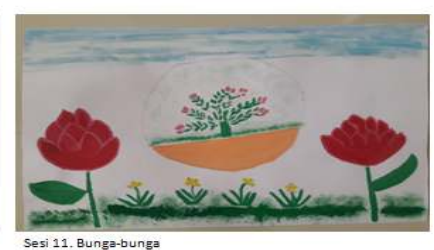

Pemilihan warna pada MA terlihat lebih terang dan garis yang ia gambar sudah semakin rapi dan berkurang ketebalannya. Hal ini mengindikasikan bahwa MA cukup mampu beradaptasi dengan proses intervensi yang ia jalani dan mulai dapat mengontrol emosi yang ia miliki melalui media seni. MA terlihat mengalami perubahan secara perlahan melalui hasil karya dari gambar yang ia buat. Komposisi ruang dan bentuk terlihat lebih proporsional dan seimbang, serta tidak banyak ruang kosong yang ada dalam gambar yang ia buat. Pemilihan warna dalam gambarnya juga terlihat semakin terang dan garis yang ia gambar sudah semakin rapi dan

Tekanan atau sapuan garis semakin terkontrol. Hal ini menunjukkan bahwa perasaan MA sudah mulai terbuka sehingga memengaruhi aspek kognitif yang terlihat dari perubahan yang ia tampilkan. Selain itu, MA juga menunjukkan perubahan perilaku seperti menjalin interaksi dengan sesama penghuni di panti dan beberapa kali terlihat berkumpul dengan penghuni panti dari barak lain. MA juga mulai mengikuti kegiatan yang diadakan panti, seperti peregangan tubuh saat pagi hari dan berjalan kaki di sekitar area panti dengan petugas.

Jika dilihat dari gambar 2, SN, menunjukkan beberapa perubahan yang signifikan. Sebelum mengikuti intervensi art therapy, SN menunjukkan perilaku seperti tidak memiliki minat untuk melakukan aktivitas atau kegiatan, interaksi sosial rendah, dan lebih banyak menghabiskan waktu untuk tidur. SN juga merasa bahwa dirinya tidak berharga karena berada di dalam panti pada masa tuanya dan jauh dari keluarga. Selain keluhan pada aspek emosi, SN juga memiliki keluhan secara fisik berupa sakit kepala dan sesak nafas yang sering kali muncul tanpa sebab yang pasti oleh SN.

Selama mengikuti proses intervensi, SN mulai menunjukkan perubahan yang juga terlihat melalui gambar yang ia hasilkan. Pada sesi awal terlihat tekanan garis pada SN tidak stabil dan 
gambar yang ia buat memiliki ukuran yang kecil. Kemudian pada pemilihan warna menunjukkan SN ingin mengekspresikan emosinya dan memilih warna-warna yang sangat menonjol. Namun, perubahaan mulai terlihat dari karya yang SN hasilkan. Gambar yang SN buat terlihat lebih memiliki garis yang stabil serta teratur, pemilihan warna yang lebih tenang dan bentuk yang seimbang tidak terlalu kecil dari kertas. Hal ini menunjukkan bahwa SN mampu untuk beradaptasi dengan baik pada intervensi yang ia jalani dan mulai dapat mengontrol dirinya melalui gambar yang ia buat.

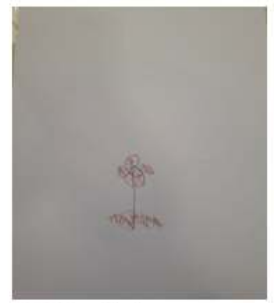

Sesi 1. Bunga Merah

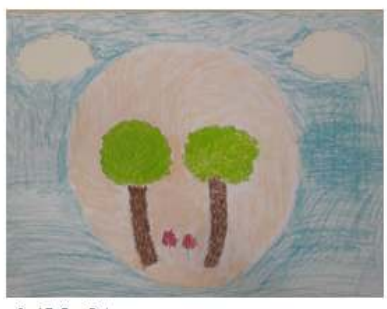

Sesi 7. Dua Poho

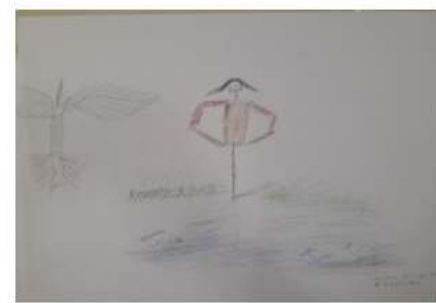

Sesi 3. Orang-orangan Sawah

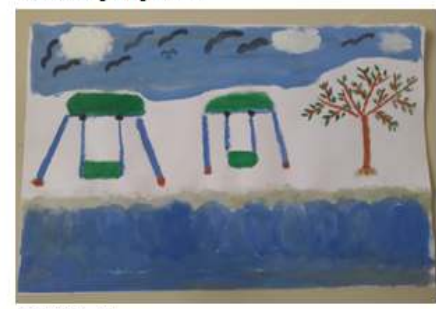

Sesi 10. Panta

Gambar 2. Hasil Intervensi Subyek 2 (SN)

Dapat terlihat dalam gambar 3, RO menunjukkan perubahan yang salah satunya terlihat dari perilaku RO. Sebelum mengikuti intervensi art therapy, RO menunjukkan perilaku seperti tidak memiliki minat untuk melakukan aktivitas, interaksi sosial rendah dan lebih banyak menghabiskan waktunya di tempat tidur. Selain itu, RO juga merasa bahwa dirinya tidak berharga, tidak berdaya di panti, mengalami penurunan berat badan dan mengganggap kehidupan orang lain lebih baik dibandingkan dirinya.

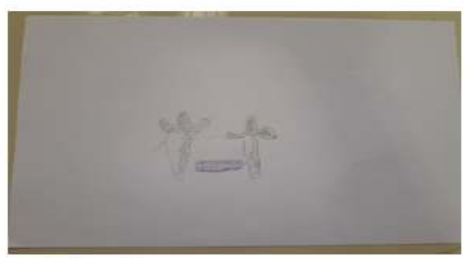

Sesi 1. Kaktus Hijau

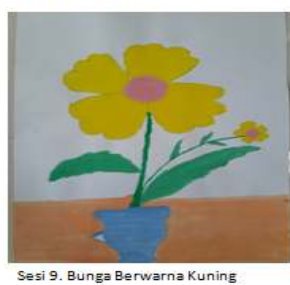

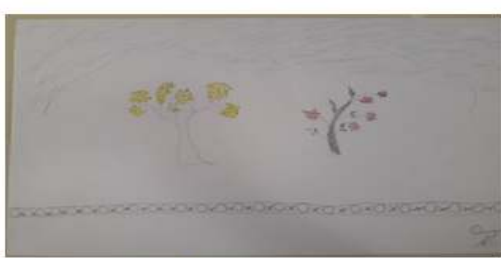

Sesi 3. Pohon Tertiup Angin

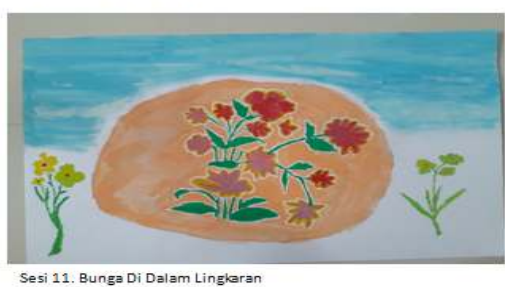

Gambar 3. Hasil intervensi subyek 3 (RO)

Saat awal menjalani intervensi, RO terlihat malu dan kurang percaya diri terhadap kemampuannya dalam menggambar. Hasil karyanya juga menunjukkan tekanan garis yang sangat kuat, gambar yang kecil dan arah goresan warna yang tidak beraturan. Secara perlahan 
RO mulai menunjukkan perubahan yang terlihat melalui gambarnya. Tekanan garis pada gambar terlihat lebih stabil, ukuran gambar yang terlihat semakin proporsional dengan ruang kertas, dan arah goresan warna yang sudah semakin rapi dan teratur. Selain itu, pemilihan warna pada hasil karya RO terlihat lebih muda dan menunjukkan ketenangan. Hal ini menunjukkan kontrol emosi pada RO sudah semakin baik.

Tabel 1

Hasil Intervensi Seluruh Subyek

\begin{tabular}{|c|c|c|c|}
\hline Aspek & Subyek MA & Subyek SN & Subyek RO \\
\hline $\begin{array}{l}\text { Skor Pre-Test melalui } \\
\text { kuesioner GDS }\end{array}$ & $\begin{array}{l}14 \text { (Kategori } \\
\text { mengalami depresi) }\end{array}$ & $\begin{array}{l}11 \text { (Kategori mengalami } \\
\text { depresi }\end{array}$ & $\begin{array}{l}12 \text { (Kategori mengalami } \\
\text { depresi) }\end{array}$ \\
\hline $\begin{array}{l}\text { Kondisi Sebelum } \\
\text { Intervensi }\end{array}$ & $\begin{array}{l}\text { Tidak memiliki minat } \\
\text { menjalani aktvitas, } \\
\text { interaksi sosial rendah, } \\
\text { kesulitan tidur, merasa } \\
\text { diri tidak berharga. }\end{array}$ & $\begin{array}{l}\text { Tidak memiliki minat } \\
\text { menjalani aktivitas, interaksi } \\
\text { sosial rendah, lebih banyak } \\
\text { tidur, merasa diri tidak } \\
\text { berharga, sering sakit kepala } \\
\text { dan sesak nafas tanpa sebab } \\
\text { yang pasti. }\end{array}$ & $\begin{array}{l}\text { Tidak memiliki minat } \\
\text { menjalani aktivitas, } \\
\text { interaksi sosial rendah, lebih } \\
\text { banyak tidur, merasa diri } \\
\text { tidak berharga dan tidak } \\
\text { berdaya selama berada di } \\
\text { panti. }\end{array}$ \\
\hline $\begin{array}{l}\text { Pencapaian Setelah } \\
\text { Intervensi }\end{array}$ & $\begin{array}{l}\text { Mulai terlihat } \\
\text { melakukan kegiatan } \\
\text { seperti stretching saat } \\
\text { pagi hari, menjalani } \\
\text { interaksi sosial dengan } \\
\text { teman sekamar atau } \\
\text { yang berbeda kamar, } \\
\text { menganggap dirinya } \\
\text { masih memiliki } \\
\text { potensi untuk } \\
\text { menghasilkan sesuatu, } \\
\text { lebih mudah memulai } \\
\text { tidur. }\end{array}$ & $\begin{array}{l}\text { Terlihat mengikuti kegiatan } \\
\text { yang diberikan panti, } \\
\text { keluhan fisik berkurang, } \\
\text { mampu menjalin interaksi } \\
\text { sosial dengan } \\
\text { lingkungannya. }\end{array}$ & $\begin{array}{l}\text { Terlihat mengikuti kegiatan } \\
\text { di dalam panti, menjalin } \\
\text { interaksi dengan sesama } \\
\text { penghuni panti, spiritual } \\
\text { meningkat, merasa dirinya } \\
\text { masih beruntung dan tidak } \\
\text { sendirian. }\end{array}$ \\
\hline $\begin{array}{l}\text { Skor Post-test melalui } \\
\text { kuesioner GDS }\end{array}$ & $\begin{array}{l}3 \text { (mengalami } \\
\text { penurunan depresi). }\end{array}$ & $\begin{array}{l}4 \text { (mengalami penurunan } \\
\text { depresi). }\end{array}$ & $\begin{array}{l}3 \text { (mengalami penurunan } \\
\text { depresi). }\end{array}$ \\
\hline
\end{tabular}

\section{Simpulan}

Berdasarkan hasil dari penelitian yang telah dilakukan, dapat peneliti simpulkan bahwa art therapy dapat menurunkan depresi pada tiga lansia yang berada di panti werdha X. Hal ini dapat terlihat melalui perubahan dari karya yang dihasilkan, observasi perubahan perilaku, proses pada tiap sesi intervensi, wawancara dan perbandingan hasil pre test dan post test pada seluruh subyek.

\section{Diskusi}

Penerapan art therapy secara efektif dapat membantu menurunkan depresi pada tiga lansia di panti werdha X. Hal ini terlihat pada ketiga subyek selama menjalani proses art therapy. Pada tiap sesi intervensi, seluruh subyek dapat mengekspresikan perasaan dan meningkatkan kepercayaan diri yang dimiliki dan menganggap diri mereka masih memiliki potensi untuk menghasilkan sesuatu. Kepercayaan diri subyek juga dikuatkan oleh reward secara verbal dari kepala dan petugas panti saat melihat hasil karya dari ketiga subyek. Temuan ini juga sesuai dengan Rubin (2010) yang menyatakan bahwa salah satu tujuan dalam pemberian teknik art therapy adalah untuk membantu individu menggapai tujuan, seperti mengungkapkan apa yang dirasakan, sebagai media katarsis, atau meningkatkan self esteem pada individu. 
Metode art therapy yang digunakan pada ketiga subyek adalah metode menggambar dan mewarnai. Awalnya ketiga subyek sempat merasa kurang percaya diri untuk menggambar dan mewarnai. Ketiga subyek beranggapan bahwa mereka sudah lama tidak menggambar dan kurang yakin dengan hasil dari gambar yang mereka buat. Namun saat menjalani intervensi, ketiga subyek terlihat dapat menunjukkan perubahan yang semakin baik pada tiap sesinya. Hal ini sesuai dengan Adriani dan Satiadarma (2011) bahwa kegiatan yang dapat dilakukan dalam art therapy salah satunya melalui kegiatan menggambar. Menggambar merupakan kegiatan yang menyenangkan dan dapat dilakukan oleh siapapun sekalipun individu tersebut tidak dapat menggambar.

Selama menjalani proses intervensi, seluruh subyek diarahkan untuk menggambar pengalaman hidup mereka di masa lalu, masa kini, dan menggambar hal yang menyenangkan bagi mereka. Melalui pendekatan yang dilakukan, seluruh subyek secara bertahap mampu untuk belajar memahami serta menyadari pengalaman mereka yang terjadi di masa lalu. Sehingga seluruh individu dapat belajar melalui pengalaman yang dialami dan mampu menyesuaikan diri mereka dengan kondisi saat ini. Hal ini juga sesuai dalam Adriani \& Satiadarma (2011) yang menyatakan bahwa dengan menggunakan media menggambar akan membantu individu untuk memahami persepsi dan perasaan mereka. Media menggambar juga membantu individu untuk mengenali cara menyelesaikan masalah dan harapan yang masih dimiliki sehingga individu akan hidup lebih baik.

Art therapy dalam penerapannya dapat melibatkan aspek fisik, emosi, dan kognitif secara bersamaan pada seluruh subyek. Aspek fisik meliputi gerak pada motorik halus serta sensasi fisik yang dapat dirasakan oleh ketiga subyek selama menjalani proses intervensi art therapy, seperti menggunakan kemampuan fisik mereka untuk menggunakan peralatan menggambar yang sudah disiapkan. Sehingga hal ini juga membantu ketiga subyek untuk lebih banyak bergerak dan melatih kemampuan motorik halus yang sudah menurun pada lansia. Hal ini sesuai dengan Moon (2010) yang mengungkapkan bahwa membuat karya seni tidak dapat terlepas dari pengalaman sensual pada indera yang dimiliki. Seni membawa pengalaman menyenangkan dari hubungan antara material yang digunakan dan hasil karya seni tersebut. Proses seni menuntut klien untuk menyentuh dunia dan berimajinasi tentang dunia kesehariannya.

Aspek emosi dalam kegiatan art therapy pada seluruh subyek terlihat melalui tekanan garis pada dari objek yang digambar oleh subyek, proporsi ukuran objek dengan kertas, dan pemilihan warna. Pada tiap sesi terlihat ketiga subyek memiliki perubahan mulai dari tekanan garis yang semakin teratur, ukuran gambar yang sebelumnya kecil menjadi lebih proporsional, dan pemilihan warna yang memberikan nuansa menenangkan serta menyenangkan bagi seluruh subyek. Hal tersebut turut memengaruhi suasana hati subyek dan kontrol emosi yang subyek miliki terhadap diri sendiri maupun lingkungan. Melalui aspek emosi yang terlihat, perasaan seluruh subyek terlihat semakin terbuka pada tiap sesi intervensi dan mampu untuk mengenali emosi yang mereka rasakan berdasarkan hasil karya art therapy. Ketiga subyek menjadi lebih sadar akan kapasitas diri yang mereka miliki. Sejalan dengan Sharf (2004) yang menyatakan art therapy merupakan ekspresi diri yang mampu membantu individu untuk mengatasi konflik yang dialami, membantu meningkatkan kemampuan interpersonal, mengurangi stress, dan meningkatkan harga diri.

Perasaan yang sudah terbuka pada subyek turut memengaruhi aspek kognitif pada diri mereka sehingga membantu menumbuhkan kesadaran dan pemikiran pada subyek. Tugas-tugas yang diberikan selama proses intervensi membantu mengaktifkan memory recollection dan emotional 
reexperience pada seluruh subyek. Dua hal tersebut membantu untuk menimbulkan konektivitas masa lalu dan masa kini sehingga seluruh subyek mampu untuk memahami kondisi dirinya saat ini dan mampu belajar atau mendapatkan insight dari pengalaman di masa lalu. Ketiga subyek juga mengungkapkan bahwa mereka mengaplikasikan pada kehidupan sehari-hari untuk mengurangi pikiran negatif dan menggantinya dengan pikiran-pikiran yang positif serta lebih menyenangkan. Temuan ini sejalan dengan Sharf (2004) yang menyatakan art therapy dapat membantu individu dalam meningkatkan kesadaran diri dan memunculkan insight.

Aktivitas menggambar dan mewarnai yang dilakukan oleh seluruh subyek selama menjalani intervensi dianggap sebagai aktivitas yang menyenangkan dan tidak menyulitkan selama mengerjakannya. Art yang bersifat rekreasional dan tugas ketiga subyek yang berbeda pada tiap sesinya turut membantu mengurangi rasa bosan pada ketiga subyek selama berada di panti. Selain tugas yang berbeda pada tiap sesi, peralatan mewarnai yang digunakan juga berbeda sehingga ketiga subyek menikmati proses intervensi yang dilakukan dan dapat menyesuaikan diri dengan peralatan yang disediakan. Hal ini sesuai dengan Landgarten (2013) yang juga menyatakan kegiatan art therapy bagi lansia sangat penting untuk memerhatikan pemilihan media dan materi, supaya kegiatan terapi dapat berlangsung dengan baik. Art therapy untuk lansia sebaiknya dilakukan dengan menggunakan mix media. Hal ini dilakukan untuk menyesuaikan kemampuan dan kebutuhan dari lansia yang mengikuti terapi.

Seluruh subyek pada penelitian ini memiliki latar belakang yang sama mengenai keberadaannya di panti. Ketiga subyek masih memiliki keluarga, namun dengan sengaja dititipkan oleh keluarganya di panti werdha. Dukungan keluarga yang rendah pada ketiga subyek dalam menjalani kehidupannya sebagai lansia turut memengaruhi ketiga subyek mengalami depresi. Hal ini sejalan dengan Hoyer dan Roodin (2003) bahwa lansia umumnya memiliki intensitas dukungan sosial yang lebih kecil daripada orang yang lebih muda, dan memicu munculnya rasa rendah diri dan depresi pada lansia. Kondisi tersebut juga yang pada akhirnya turut memengaruhi kondisi fisik dan psikologis yang lemah pada lansia selama berada di Panti Werdha.

Rubin (2010) berpendapat bahwa art therapy memiliki waktu untuk pengerjaan dan waktu untuk merefleksikan diri dengan proporsi yang beragam. Pada tiap individu hal tersebut disesuaikan dengan keperluan dan kemajuan terapi yang diberikan. Hal ini sesuai dengan temuan peneliti di lapangan, yang menunjukkan bahwa proses dan waktu pengerjaan selama intervensi berlangsung berbeda pada tiap subyeknya. Pada subyek MA dan RO, waktu yang dibutuhkan untuk memikirkan gambar yang ingin dibuat lebih sebentar daripada subyek SN. Hal ini turut memengaruhi proses pengerjaan gambarnya sehingga pada subyek SN lebih membutuhkan durasi waktu pengerjaan yang lebih lama daripada subyek MA dan RO.

Teknik relaksasi yang sempat diberikan sebanyak dua sesi juga terlihat bermanfaat bagi ketiga subyek penelitian. Pada subyek MA misalnya, teknik relaksasi dapat membantu dirinya mengatasi kesulitan tidur yang dialami. Sampai pada proses evaluasi, MA menyatakan masih menggunakan teknik relaksasi untuk membantunya tetap tenang saat malam hari. Begitu pula pada subyek SN dan RO, teknik relaksasi masih mereka gunakan saat mereka merasa cemas atau merasa kondisi emosinya sedang kurang stabil.

\section{Saran}

Saran Untuk Penelitian Selanjutnya. Diharapkan dapat diterapkan atau menggabungkan metode art selain dengan metode menggambar dan mewarnai. Terdapat beberapa media lain 
dalam art therapy, seperti clay, merajut atau collage. Selain itu, disarankan agar menambahkan sesi group art therapy pada penelitian berikutnya. Hal ini dikarenakan, peneliti hanya satu kali memberikan sesi group therapy. Padahal sebenarnya penerapan group therapy cukup efektif untuk diterapkan karena membantu melatih hubungan interpersonal seluruh subyek dan langsung terlihat gambaran peran antar subyek selama proses group therapy berlangsung.

Saran Untuk Pihak Panti. Saran bagi pengurus/petugas panti agar mempertahankan dalam meneruskan kegiatan dengan art pada penghuni atau warga binaan di dalam panti. Panti juga dapat menambah kegiatan yang menyenangkan dan diadakan secara rutin bagi para lansia. Selain itu, pihak panti diharapkan dapat lebih peduli pada warga binaan/lansia yang masih memiliki keluarga sehingga dapat dibantu untuk berkomunikasi dengan pihak keluarga atau mengingatkan pihak keluarga untuk datang mengunjungi lansia yang ada di Panti.

Saran untuk Partisipan Penelitian. Saran bagi ketiga subyek agar terus mempertahankan perilakunya saat ini dengan tidak pernah berhenti untuk membuat karya seni pada waktu senggang di panti. Subyek juga disarankan mengingat teknik relaksasi yang sudah diberikan sehingga mampu diterapkan sendiri guna membantu mengontrol emosinya. Subyek juga disarankan lebih meningkatkan interaksi sosialnya dengan para penghuni panti sesama barak maupun di luar barak. Subyek juga disarankan untuk lebih terbuka pada dukungan sosial yang diberikan oleh petugas maupun orang lain yang berada di sekitar subyek saat ini.

Saran untuk Keluarga. Saran bagi keluarga agar lebih sering melakukan kunjungan pada lansia yang dititipkan di panti. Keluarga juga disarankan dapat menunjukkan dukungan morilnya pada mereka. Selain itu, jika memungkinkan disarankan pihak keluarga mau untuk membawa pulang lansia terutama saat hari besar keagamaan ataupun saat hari libur nasional.

\section{REFERENSI}

Adriani, S. N. \& Satiadarma, M. P. (2011). Efektivitas art therapy dalam mengurangi kecemasan pada remaja pasien leukemia. Indonesian Journal of Cancer, 5(1), 31-47.

American Psychiatric Association. (2000). Diagnostic and statistical manual of mental disorders (4th edition, text revision). Washington DC: Author.

Blazer, D.G. (2003). Depression in late life: Review and commentary. Journal Gerontology Medical Science, 58A, 249-265. http://focus.Psychiatyonline.Org/cgicontent/full/7/1/118.

Bolton, G. (2008). Dying, bereavement, and the healing arts. London: Jessica Kingsley Publishers.

Cohen, G. (2000). The creative age. New York: Harper Collins Publisher.

Gallo, J.J., \& Gonzales J. (2001). Depression and other mood disorder. In: Adelman AM, Daly MP, and Weiss BD, eds 20 Common problems in geriatrics. New York: McGrawHill.pp.205-235.

Ganim, B. (2013). Art and healing: Using expressive art to heal your body, mind, and spirit. New York: Echo Point Books \& Media.

Gunarsa, S. D. (2004). Dari anak sampai usia lanjut: bunga rampai psikologi anak. BPK Gunung Mulia: Jakarta.

Indrawati, E. S., \& Saputri, M. A. W. (2011). Hubungan antara dukungan sosial dengan depresi pada lanjut usia yang tinggal di panti wredha wening wardoyo jawa tengah. Jurnal Psikologi Undip, 9 (1), 65-72.

Landgarten, H. B. (2013). Clinical art therapy: A comprehensive guide. New York: Routledge.

Lubis, N. L. (2009). Depresi: Tinjauan Psikologis. Jakarta: Kencana Prenada Media Group.

Malchiodi, C. A. (2007). The art therapy sourcebook. New York, NY: McGraw-Hill. 
Malchiodi, C. A. (2012). Handbook of art therapy (2nd ed.). New York: The Guildford Press.

Malchiodi, C.A. (2013) What is art therapy? Diunduh dari http:/www.psychologytoday.com/blog/the-healing-arts/201304/defining-art-therapy-inthe-21st-century.

Stephenson, R. C. (2006). Promoting self expression through art therapy. Journal of Proquest Sociology, 30, 24-28.

Wardhana, H. (2014, 29 Mei). Mereka lansia mereka berdaya. Kompasiana. Diunduh dari http://www.kompasiana.com/wardhanahendra/mereka-lansia-merekaberdaya_54f72ff1a33311b06d8b4693. 